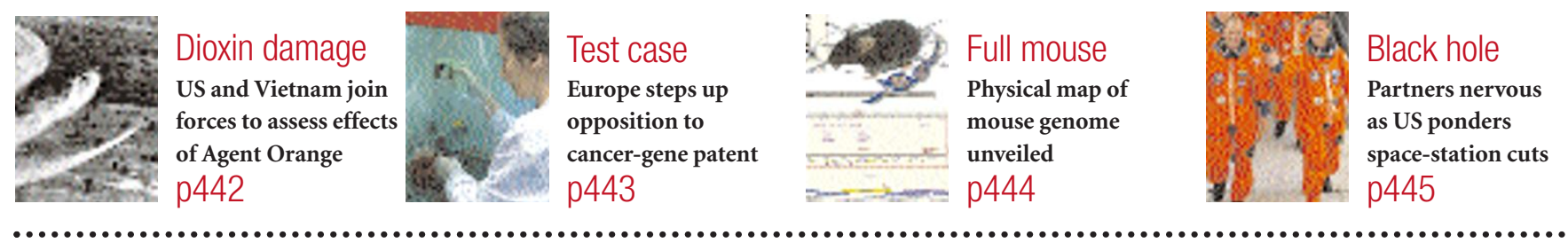

\title{
Large Hadron Collider in crisis as magnet costs spiral upwards
}

\section{David Adam, London}

Europe's attempt to build the world's most powerful particle accelerator was plunged into crisis this week as project managers admitted that it faces cost overruns of several hundred million dollars.

CERN, the European particle physics laboratory, where the Large Hadron Collider (LHC) is being built, will face years of budget cuts and belt-tightening as a result of the overruns, its management told staff. But this will cover only a fraction of the extra costs, and CERN is preparing to take the awkward step of asking its 20 member states to cover the rest.

Scheduled to open in 2006, the LHC is intended to be the world's next major high-energy physics facility. But the technical challenge of designing and building the superconducting magnets needed to steer protons and ions through the LHC's accelerators has proven more difficult - and expensive - than CERN expected. Problems with such magnets contributed to the 1993 demise of the US Superconducting Supercollider.

CERN says that the higher costs of the magnets, together with greater installation and civil engineering costs, have put the core project some SFr480 million (US\$300 million) over its original SFr2.6 billion budget. But scientists at CERN who have been briefed on the situation say it could cost at least SFr3.4 billion - SFr800 million more than initially planned - to get the LHC up and running. Prototype magnets already built have cost the laboratory about SFr150 million more than it expected, and some SFr220 million extra must also be found to install detectors and to pay for computers.

CERN now has until 7 November to come up with a rescue plan to present to its finance committee, made up of representatives from the European countries funding the facility. "The organization is reviewing various possible options including cuts in the scientific programme, reductions in spending within the organization, bank loans and extra contributions from member states," says Neil Calder, a spokesman for CERN.

At a crisis meeting of staff and users on 1 October, CERN director-general Luciano

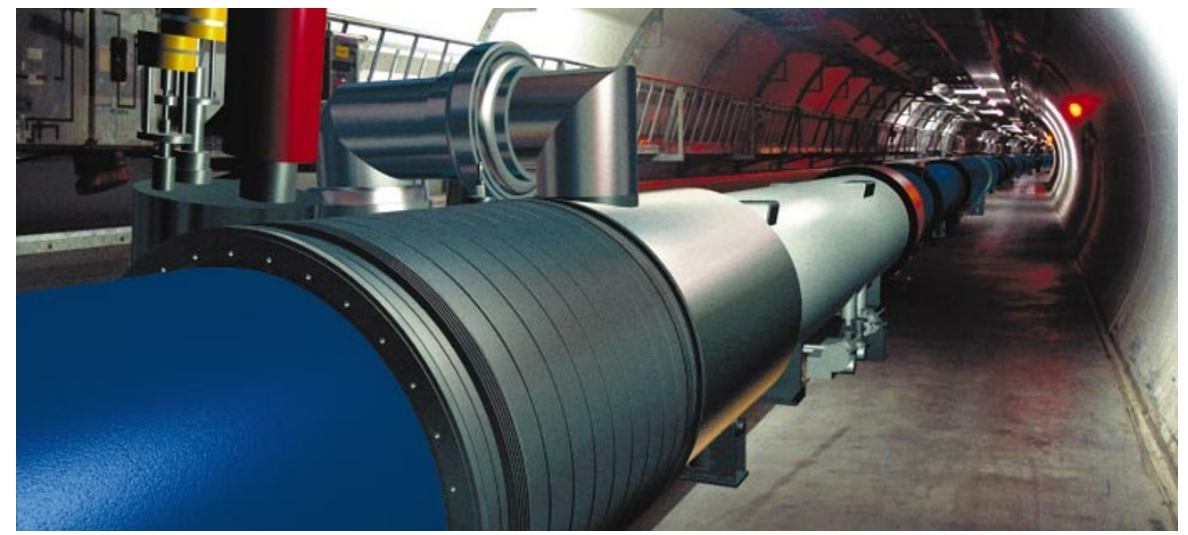

Running short: CERN may turn to its member states for the cash to finish the Large Hadron Collider.

Maiani said that the organization was aiming for $10 \%$ cost reductions across all divisions. "Basically we're looking at austerity measures over the next few years to pick up the slack," says one CERN researcher.

Some researchers expressed unhappiness that they first learned of the problems from an article in a local newspaper. Their irritation is shared by the CERN member govern- ments who are paying for the project.

A spokesman for the Particle Physics and Astronomy Research Council, which pays Britain's annual $\mathfrak{E} 65$-million (US\$96million) subscription to CERN, says that the situation is "potentially very serious". But he says he will wait for the November meeting before commenting on the possible implications for British physics and astronomy.

\section{Senators call for biodefence boost}

\section{Jonathan Knight}

A massive increase in public-health spending is needed to prepare the United States for a possible terrorist attack with biological weapons, two prominent US senators say.

In response to the attacks on the World Trade Center and the Pentagon on 11 September, Senators Edward Kennedy (Democrat, Massachusetts) and Bill Frist (Republican, Tennessee) say that the US government should spend $\$ 1.6$ billion next year to bolster public health and biodefence.

According to a report from the General Accounting Office, federal spending on bioterrorism readiness, including research, amounted to about $\$ 350$ million in the 2001 fiscal year, which ended on 30 September.

Although this is a significant increase from previous years, biodefence efforts are poorly coordinated, the report says. For example, several agencies disagree over which pathogens should count as potential threats. In addition, most hospitals are poorly prepared to detect or handle a massive outbreak of disease.

To remedy this, the Kennedy-Frist proposal includes $\$ 625$ million for state and local health agencies — a sixfold increase.

"There does seem to finally be an acknowledgement that the public-health infrastructure is in deep disarray," says Alan Zelicoff, a biodefence expert at Sandia National Laboratory in New Mexico.

Mark Wheelis, a microbiology professor at the University of California, Davis, says that the large number of ways an attack could be perpetrated will make it hard to decide how best to spend the money. 